\title{
The Poet and his Doubles: Claudel's Orientalism
}

\author{
Madhuri Mukherjee \\ William Paterson University
}

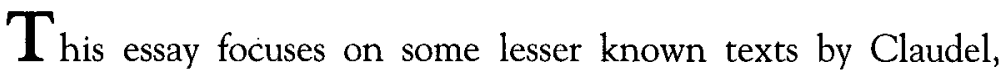
namely, La Légende de Prâkriti, Conversations dans le Loir-et-Cher, Le Poète et le Shamisen, and Le Poète et le Vase d'encens. All these texts have in common a loosely theatrical framework, presenting two or more characters engaged in dialogue. In each text, Claudel has provided nominal stage directions, and cursory indications about the decor. Moreover, the Orient, its religions, its philosophies, and its people, are often the subject of discussion in these texts.

My goal is to suggest that the extent to which the theatrical mode is exploited in these texts often serves as an indicator of the degree of conviction Claudel appears to have in his ideas, as well as of the "orientalism" of these ideas.

To begin with La Légende de Prâkriti:

In a preface published for the first time in 1965, Claudel chooses to acknowledge the rather obvious-the fact that he borrows the name Prâkriti from Indian philosophy:

Qui est Prâkriti? Je me suis permis d'emprunter son nom à une école de philosophie indienne. ${ }^{1}$

Claudel seems to be referring to the Sankhya school of Hindu philosophy, in which Prakriti occupies a position similar to that of Maya (the universe as illusion) in other Hindu philosophic schools. The important difference, however, between the two personifications is that Prakriti is considered real and independent, whereas Maya is totally subordinate to Brahma, and subject to His command. Prakriti, in Hinduism, may be described as the primal, undifferenciated, universal substance, containing within itself all potential creation and evolution. In the above-mentioned preface, however, Claudel explains Prakriti as follows: 
Prâkriti est ce que l'on a appelé quelquefois la nature naturante. C'est, si vous voulez, quelque chose comme une raison sociale. C'est tout ce qui dans la réalité autour de nous est capable de répondre solidairement à une invitation, à une commande apportée du dehors, ainsi que Michel-Ange fit à celle du Pape Jules II pour la Chapelle Sixtine.

The above description shows how Claudel intends to use the idea of Prakriti for his own ideological ends. On the one hand, he affirms the reality of the universe, because Prakriti is the antithesis of the concept of Maya. However, he then proceeds to modify the original Indian concept. What is retold as the legend of Prakriti, whom the author addresses easily and familiarly as "notre vieille Prâkriti" (OP 951) is Claudel's own theory of creation and evolution. Prakriti, in Claudel's version is not the primal, undifferentiated substance she is in Hinduism, from whom all forms emanate, for he clearly states:

Prâkriti n'est pas une sorte de déesse immanente qui pourvoit comme dans un rêve à l'innombrable diversité des êtres par une série indéfinie et de plus en plus détaillée de bourgeonnements et de scissiparités (...). (OP 960)

Claudel's Prâkriti is Christian, corresponds to the Western idea of nature, and although she is sometimes capable of misunderstanding instructions, or indulging in puns ("Par exemple on lui dit: Cheval, et elle fabrique aussitôt cette ridicule petite piece de jeu d'échecs qu'on appelle un hippocampe, qu'elle lâche dans son aquarium." OP 964), she is not an independent originator of creation, she is only responding to "une commande apportée du dehors".

At the formal level, La Légende de Prâkriti reveals itself as a peculiar fusion of multiple genres. Although it is a philosophical essay, expressing its author's theories on evolution, creation, and transformation, Claudel's admiring and ecstatic descriptions of the mischievously mysterious workings of Prâkriti confer on the Légende an intensely poetical quality, evident, for example, in the following excerpt: 


\section{The Poet and his Doubles: Claudel's Orientalism}

Et quand on la gronde elle ferme les yeux, et avec un sourire enchanteur, d'une rose aussi pure que le souffle d'une jeune fille elle exhale un papillon. (OP 964)

Such lyrical language justifies the description and classification of the Légende as a prose poem. (In the preface, Claudel refers to it as "... un poème, une espèce de parabole.") However, at the same time, the poet endows it with elements of a theatrical framework:

Je suppose que remontant le cours des âges et entouré d'un groupe d'auditeurs sympathiques un vieux rêveur est arrivé à portée de ce bruit que font ces eaux dont nous parle la Genèse en s'échappant du Paradis terrestre. C'est un beau jour d'été, les cotons des saules et des peupliers descendent sur les cheveux du groupe attentif et une abeille de temps en temps vient se prendre dans la barbe de l'orateur inspiré. (OP 1525)

Although this idyllic scene is purely imaginary, it nonetheless involves a certain mise en scène: the characters ("un vieux rêveur" and "un groupe d'auditeurs sympathiques") play out their roles in a scenic stage set, complete with realistic details ("les cotons des saules et des peupliers," "une abeille"). The opening line of the text ("Le Maître ouvrant la bouche, ajouta ces paroles:" OP 944) which is in the third person, and in the past tense, remains grammatically and temporally separate from the discourse of the Maître. This speech, enclosed within quotation marks, constitutes the body of the Légende, and is delivered in the first person, and in the present tense. The final short paragraph, again distinctly separate from the main text of the Légende, recalls, and closes, the theatrical framework:

Là-dessus le Maître, ayant cessé de parler, se tut, et les disciples s'étant regardés les uns les autres, chacun d'eux s'apercevant dans les yeux de son voisin qu'il n'avait rien à dire, il ne dit rien. (OP 968-9)

The disciples have only a silent role. What announces itself structurally as a dialogue, then, is actually a monologue, and the Légende may, in this respect, be considered a form of theater of the self. "Le Maître," "un vieux 


\section{Madhuri Mukherjee}

rêveur," "l'orateur inspiré," represent a created double, a character that allows the author to hold forth on his personal point of view. And since the point of view in this essay is unambiguous, a single voice serves the purpose.

Where the point of view is double, or multiple, where the ideas to be expressed have yet to attain the certainty of conviction, or where the author's attitude is in part conciliatory, plural voices are necessary. Such a plurality of voices structures Claudel's Conversations dans le Loiret-Cher, a series of texts characterized again by a confusion between theatrical, poetical, and prose genres. The multiple, unidimensional characters in these Conversations contrast sharply with superheroes such as Tête d'Or and Christophe Colomb in Claudel's plays of conquest. Conversations dans le Loir-et-Cher

Each of the four Conversations has a specific decor. The first, "Jeudi," takes place on "une terrasse devant un petit château...," (OP 669) while the last, "Samedi," takes place, not unlike Partage de Midi, on a ship, "qui revient de l'Extrême-Orient." (OP 776) "Dimanche" takes place in mid-stream: "Les personnages en deux bateaux rament et flottent paresseusement sur le Loir-et-Cher." (OP 700) "Mardi" opens against the backdrop of "Une levée de la Loire entre Chaumont et Amboise" (OP 735) where an automobile has just broken down. The characters push the vehicle out of the way. The change of scene, and the decor for the ensuing Conversation, is very poetically described by Civilis:

Poussons le tacot la-dessous, ici! à l'ombre de ces beaux noyers, et nous assis à la fraîche sur ce mur sec et chaud et sur cette charrette abandonnée, nous attendrons que la Loire ait fini de couler, tandis que les grosses cerises d'elles-mêmes nous tomberont une par une dans la bouche. (OP 735)

In addition, parenthetical indications such as, "Il fait le geste d'éloigner son bateau," (OP 711) or "Il revient avec un panier et des bouteilles. Tous mangent et boivent" (OP 755), punctuate the text, attempting to maintain the illusion of theater. These indications are clearly presented as stage directions, and not as mere description or narration. The form of Conversations thus pretends to be theatrical by the incorporation of decor, stage directions, and by the way the written aspect of the texts resembles that of traditional plays. However, the char- 


\section{The Poet and his Doubles: Claudel's Orientalism}

acters remain unidimensional, each responding to the subject under discussion in one typical fashion, as can usually be anticipated from the name each bears. Acer's is the voice of irony and contradiction, of acerbic barbs; Furius expresses passion, violence, and intensity; Civilis personifies temperance and moderation. In a sort of symphonic concert, each fictitious double of the author contributes his or her perspective. The result is a dynamic flow of ideas and associations, which render the Conversations different from other literary dialogues, for example, the classical, Socratic dialogues, in which the exchange of responses leads to a predetermined demonstration or conclusion. Claudel's Conversations borrow less from the conventional, classical, literary or philosophical genres mentioned above, than from theater of improvisation. A metacommentary by the character Grégoire, in fact, asserts, by way of a hypothetical opposition, an affiliation to theatrical tradition:

C'est amusant que de sentir ainsi nos pensées qui naissent l'une de l'autre. Pourquoi les dramaturges au lieu d'opposer des personnages qui heurtent sans se les pénétrer des theses antagonistes, ne montrent-ils pas l'idée qui passe comme une flamme d'un esprit à un autre et se développe en un jeu de propositions alternées qui prennent appui l'une sur l'autre comme dans les églogues de Virgile et de Théocrite? C'est comme la navette sur un métier. (OP 787)

The above excerpt, from the Conversation entitled "Samedi" occurs right in the middle of an extended discussion about Asia, and the nature and temperament of Asiatic people. The form of the spontaneous conversation lends itself par excellence to the expression of Claudel's ambiguous orientalism, for it enables the author to hide behind his fictitious doubles, distancing himself from the views and judgments they express. The extreme freedom of the form engenders a parallel freedom of expression, and enables a character even to contradict himself, or change his mind, within the same text. This is in stark contrast to Claudel's exegeses and treatises in which the argument is outlined beforehand, in numbered paragraphs, of which the ensuing text presents a strict and logical amplification. This point is clearly illustrated by considering an example, and examining the threads of the conversation relating to Asia in "Samedi." The last of the Conversations, this one does 


\section{Madhuri Mukherjee}

not feature the troupe of Acer, Furius, \& Co., but is actually a dialogue. The protagonists in this case are Grégoire, an Armenian dealer in antiques, and Saint-Maurice, an aviator.

SAINT-MAURICE. - ...vous croyez qu'il y a une idée commune à tous ces peuples de l'Asie?

GREGOIRE: Je le crois.

SAINT-MAURICE. - Quelle est-elle?

GREGOIRE. - L'attention à la racine.

SAINT-MAURICE. - C'est pour cela que le Bouddha se regarde le nombril?

GREGOIRE. - C'est pour cela que je me suis fait antiquaire.

SAINT-MAURICE. - Je me sens dans le cerveau un petit chatouillement avant-coureur qui me dit que je ne vais pas tarder à comprendre. (OP 784)

This excerpt is followed by a poetic and allegorical digression, relating to antiques, after which Grégoire gets back to the subject under discussion:

GREGOIRE. - (En Asie) ... tout est calculé pour empêcher l'humanité de bouger de place. Rien que la forme de ces contrées, le triangle dans l'Inde la pointe en bas comme celui du ventre, le cercle en Chine comme un abdomen, ou ces îles recourbées qui se regardent elles-mêmes comme au Japon, suggère l'idée d'une prison mystique. A l'intérieur de cette géometrie symbolique tout a été calculé pour obliger l'être humain à la fixité... (OP 785)

Grégoire then offers several examples to illustrate his contention, and concludes with the words:

Il fallait dans l'humanité quelque chose qui assure la continuité. C'est de quoi est chargée l'Asie qui par d'énormes racines ne cesse d'être attachée à l'origine même de la race et qui lève les yeux vers l'éternité. (OP 786) 
The two characters then engage in an extended exchange of thoughts and ideas, flitting from subject to subject, touching upon the attitude of Orientals toward money and material comforts, their talkativeness, their nomadism ("... car il n'y a pas de meilleur moyen d'affirmer sa prison que d'en vérifier tous les murs," OP 786), Russia and Communism ("Rien n'aide à comprendre le régime communiste comme celui des castes de l'Inde ou de la famille chinoise" OP 787), oriental art, oriental carpets ("Dès que l'Occident a vu ces tapis, il les a redressés, il les a interposés entre lui et le devoir éternel de la route et il en a fait les vitraux" OP 787). After these meanderings, the conversation turns to America, to progress and industry:

L'Amérique ne parle pas, elle chante, elle ronfle, elle compte, elle tourne indéfiniment sur elle-même comme une dynamo insérée entre les deux Pôles et les deux bouts du Continent. C'est le tic-tac de la machine universelle qui est devenu perceptible. Elle ne secrète plus d'autre loi que l'huile nécessaire à sa propre lubrification, cette hygiène qu'elle a substituée à la morale. (OP 789)

The character speaking is still Grégoire. After having circumnavigated the globe, with comments on Asia, Russia, and America, the dialogue returns to the point of origin, with now, a radical transformation of perspective. The symbolic trip around the world has made him realize that "une prison mystique" may not be such a bad thing after all, and he exclaims:

Comme l'Asie est rafraîchissante quand on arrive de New York! Quel bain d'humanité intacte! Elle n'a pas fini de nous approvisionner de questions et de problèmes, par son silence aujourd'hui comme autrefois par ses livres. Elle n'a pas rompu son pédoncule. Elle est en communication avec l'origine. (OP 789)

In these texts, every aspect of Claudel's complex personality is allowed expression, and the author of Conversations is, thus, truly the sum of his parts.

This form of self expression, namely, the author's conversations with invented characters, takes a slightly different form in Le Poète et le 
Shamisen (June 1926) and in Le Poète et le Vase d'encens (August 1926). On the one hand, the poet appears as himself-le Poète-, and the pretense of fictitious characters (Acer, Furius, etc.) articulating his thoughts, is done away with. On the other hand, in these two texts, the poet's double, his verbal sparring partner, is not even conventionally human: in both cases, the poet converses with objects; these objects, furthermore, are oriental objects.

Le Poète et le Shamisen is a text in which many of Claudel's aesthetic ideas and opinions find expression. Within this meandering dialogue, which is really a monologue, Claudel comments on diverse topics, such as the Bounrakou and Nô plays he had recently seen, Chinese painting, Japanese architecture, Japanese landscapes, the relative aesthetic appeal of various geometric figures such as the triangle, the square, and the circle, the poetry of Paul Valéry, and so on. In a most interesting way, Le Poète et le Shamisen asserts an affiliation to Symbolism, and specifically to Rimbaud's articulation of its aesthetic. Claudel's text appears to be a literal demonstration and mise en scène of the musical metaphors employed by Rimbaud in the two Voyant letters. I am referring to the lines "Tant pis pour le bois qui se trouve violon", "Si le cuivre s'éveille clairon, il n'y a rien de sa faute", and most particularly to “...j'assiste à l'éclosion de ma pensée: je la regarde, je l'écoute: je lance un coup d'archet: la symphonie fait son remuement dans les profondeurs, ou vient d'un bond sur la scène"2 (emphasis mine). In Claudel's text, he is literally both "je",- le poète-and "autre",-- the double who observes, listens, and responds to the self. Although the Other in this dialogue is an inanimate object, it is, nevertheless, like in Rimbaud's metaphor, represented as a stringed musical instrument, capable of proffering varying degrees of response to the poet's "coup d'archet". These responses range from a laconic, facetious, onomatopoeic "Tarara, boum, boum, gdnn, gdnn" (OP 832) with which the Shamisen punctuates the end of a lengthy development by the Poet of the difference between a Greek triangle and a Japanese one, to a chiding retort provoked by the Poet's statement "Je ne suis pas bouddhiste" in response to a reference by the Shamisen to Karma, the destiny which brought the Poet to a specific region of Japan. The Shamisen tells the Poet:

Il n'y a pas besoin d'être bouddhiste pour croire à la fatalité pour nous de certains coins de la terre, une attraction, une occulte parenté, une porosité à certaines influences non seulement des sens mais de ce qu'il y a en nous 
d'éternel, une communication, la succion de notre temps personnel par l'immense temps de la nature. (OP 830)

The Other within the self thus becomes explicitly oriental, and serves as a literal sounding board to test the viability and direction of the poet's nascent thoughts and ideas. At the same time, in Claudel's case, this double voices those unorthodox thoughts that the Self could not express without compromising its chosen stance, the role of intransigence it has decided to assume.

In Le Poète et le Vase d'encens, the incense-burner that is the poet's created double, plays two roles. On the one hand, it serves as a lamp shedding light on darkness, and on the other, it exhales perfume. The poet associates this exhalation with the breath of life, and requests the help of the Vase d'encens in reconstituting certain papers and manuscripts that were burnt in the aftermath of an earthquake which destroyed the poet's house. The papers that were destroyed consisted of notes for an essay on the ancient Hindu shrine of Angkor Vat, which Claudel had visited on a 1925 trip to Indochina. It was at Angkor that Claudel saw, represented in stone, a version of the ancient Hindu myth of the Churning of the Ocean of Milk that he was to dramatize two years later in Le Livre de Christophe Colomb:

LE POETE. - C'est ici le grand marécage, la Mer de lait dont il est parlé dans le Ramayana et que les dieux ont barratté aux jours de la création, se servant du grand Serpent primitif comme ribot. On voit cela dans un style rondouillard et mollet sur une des pages de pierre qui décorent le péristyle d'Angkor Vat. Les dieux bons sont d'un côté, les mauvais génies de l'autre, affrontés en une double file interminable que dominent de distance en distance les Seigneurs, les Tours, Brahma, Siva, le Singe Hanuman. Attelés à la corde ils se livrent à leur tug-ofwar cosmogénique. (OP 838-39)

One of the many creatures to emerge as a result of the churning of the Sea of Milk were the Apsaras, or celestial dancers. Their dancing is generally associated with what is known as the spirit of bhakti, or devotion. Observing the many sculptures at Angkor depicting these heavenly 
nymphs, “... sur tous les piliers, agitant gracieusement leurs palpes," (OP 838) the Vase d'encens requests further illumination from the poet:

Puisque tu es si savant, dis-nous aussi que cette danse frénétique et vaine, c'est ce que les Hindous rattachent au sentiment appelé bhakti. Dieu créant le monde sans aucune raison, dans le transport de sa joie, dans le délire de son ivresse. (OP 839)

The poet, however, has a different view of what the dance represents:

Pour moi c'est l'évolution des anges imitée par le trépignement des damnés, ce sol dont ils ne peuvent s'arracher. (OP 839)

Aside from the description of a couple of specific sculptures, the major focus of Le Poète et le Vase d'encens is a development of Claudel's impressions of Angkor, which he describes as "un des endroits les plus maudits que je connaisse", one that archaeologists would do well to abandon to the forest that threatens to engulf it. The two distinctive characteristics the poet notes about the architecture of the temple are, on the one hand, the numerous still water ponds, and on the other, a vertical arrangement of perspective, which he refers to as a "mouvement de bas en haut". Concentrating on these two architectural features, the poet attempts to demonstrate how they are symbolic of all of Asia. It is not hard to gather, from this passage, that for Claudel, the shrine, with its unmoving waters, and emphasis on the vertical gaze, is, in fact, a microcosm of Eastern religion, Eastern mysticism, the Eastern attitude and mentality.

With prodding and help by the Vase d'encens, this thesis is very poetically and seductively developed in an accumulation of propositions. The following extracts illustrate the nature of the argument, and the sheer lyricism of the poet and his double:

LE VASE D'ENCENS. - Si tu suis ton idée avec logique, tu finiras par tout retrouver. Je t'aiderai. Et je commence par poser la question: Qu'est-ce que l'étang?

LE POÈTE. - L'étang c'est l'eau immobile. 
LE VASE. - Le miroir. L'eau qui commence à refleter dès qu'elle s'arrête. Pareille au néant, image du vide et reflet de tout.

LE POETE. - L'eau thésaurisée et stagnante, exactement adéquate à son cadre. A l'état de niveau. Immobile. Consciente d'elle-même, totalisée dans le poids, échappant à l'éternité par le moment.

LE VASE. - Prise ailleurs et retenue (le souvenir), sans source, sans écoulement. Emblème de la séparation et de l'exil.

(...)

LE POETE. - L'eau parquée, emprisonnée, condamnée, incapable de s'échapper et de fuir.

LE VASE. - Inutile, n'ayant de vertu que pour refléter et non plus pour atteindre. Conservant tout ce qu'on lui confie et l'analysant, le corrompant. Les vers y vivent, les insectes de la mort y pondent.

(...)

LE VASE, - Elle est morte, elle est excommuniée. La prison l'a rendue éternelle à la même place. Elle ne pousse pas. Elle n'est plus poussée. Elle cuit, elle ne circule plus. Elle a cessé de servir et d'obéir. Elle a cessé d'être acte, pour devenir cette espèce de toute-puissance à rebours qu'est le néant. (OP 841-42)

The dialogue is a thinly veiled condemnation of oriental spiritualism; once the word "l'eau", and its pronoun, "elle", are replaced by the words "l'âme orientale" or "l'âme asiatique", Le Poète et le Vase d'encens echoes the lesson recited by the Demon in Le Repos du septième jour, the commentaries on Hinduism and Buddhism in Emmaüs and Isaie, and the general descriptions of the immobility of the Asiatic temperament to be found in Conversations dans le Loir-et-Cher. And although Claudel does not explicitly equate the two (water and the oriental soul), in Mémoires Improvisés, he speaks of oriental mysticism as being equal to a sort of dissolving of personality, a liquefaction: 


\section{Madhuri Mukherjee}

L'homme est indéchirable, somme toute, et c'est justement la leçon de Connaissance de l'Est que jamais il n'y a abandon d'aucune des facultés, et en particulier de la volonté. Je ne suis pas un ascète hindou, je ne suis pas prêt à me liquefier comme une poupée de sel, comme disent les mystiques hindous, dans une mer de délices, une mer de joies.

The second part of Claudel's demonstration, i.e. why a vertical perspective in art and architecture reflects the mystical prison within which Asians are bound, involves a contrast with the West, with Europe:

LE VASE. - Ce mouvement de bas en haut...

LE POETE. - ...n'est-il pas caractéristique de toute l'Asie? Ce qui va de bas en haut c'est l'esprit. Ce qui va de bas en haut c'est qu'il ne peut aller ailleurs et qu'autour de lui sur le même plan, à gauche, à droite, tout absolument est fermé et que la volonté est assise sur des diamètres égaux. (...) L'Inde est un triangle et la Chine est un segment de cercle, les deux formes géometriques. de la fermeture, car on peut s'échapper d'une prison, mais on ne peut pas s'échapper d'un triangle. (OP 84142)

On the other hand, continues the poet:

En Europe tout est disposé pour la direction horizontale face au spectateur, tout est avenue et vallée vers la mer. (...) Où va l'oeil le pied le suit. Tout est à portée de la main... (OP 842)

The conclusion of these observations is, therefore:

Pendant que l'esprit (asiatique) pratique ainsi de palier en palier son ascension, comment le corps pourrait-il changer de place? Il est occupé éternellement à mesurer ce qui est là devant lui et qui l'empêche de passer. Celui qui regarde de bas en haut attend et prie, celui qui regarde droit devant lui désire et conquiert (...). Le pre- 


\section{The Poet and his Doubles: Claudel's Orientalism}

mier regarde toutes les hauteurs d'où ça redescend vers lui-même, le second est comme tiré en avant... (OP 843)

This extract recalls once again the superheroes in Claudel's plays of conquest (Tête d'Or and Christophe Colomb who look straight ahead, desire, and strive to conquer), as well as the lesson learned by the King in Le Repos du septième jour, namely, that Buddhism is "la Connaissance invertie; la fin retournée sur la cause".

Through most of its development, Le Poète et le Vase d'encens appears to be an exchange of ideas between two like-minded protagonists, each adding to what the other proposes, in order to reach a common conclusion. However, the Vase d'encens proves to be more truculent a partner than the Shamisen; this created double seems to develop a life of its own, to want to assert its individuality and alterity. Arguing about Tao Te King, and commenting a text by Lao Tzeu, the first signs of animosity begin to creep in between the Poet and his double. Reacting to a proverb from Confucius quoted by the Vase d'encens, the Poet exclaims:

Comment dis-tu? Horrible, idiot, scandaleux! C'est trop! $\mathrm{Tu}$ vas trop loin! $\mathrm{Ah}$, tu flattes mes plus mauvais instincts, tu dévoiles cyniquement mes pensées inavouables! Je t'écoute avec remords et ravissement! (OP 845)

The ambiguity the Poet feels toward oriental philosophy is apparent here, as he reveals that the Vase d'encens has pierced his innermost thoughts. The Vase d'encens proceeds to tell a couple of stories, meant to allegorically illustrate certain precepts of Tao, specifically what he refers to as the "théorie du Vide". This theory is explained as:

\section{(...) les procédés du Suprême Artiste et de l'Homme d'Etat qui agit en n'agissant pas et dans tout ce qu'il fait s'efforce à imiter le hasard, le hasard étant la seule chose contre laquelle les dieux n'ont pas de puissance. (OP 846-7)}

The ambivalent Poet's curiosity is piqued; on the one hand he is eager to hear these stories, while on the other, given his religious convictions, he 
would prefer to turn a deaf ear. His reaction thus swings from an emphatic "Non! je me bouche le nez! je ne peux pas t'entendre!" to a pleading "Ne fais pas le méchant! raconte!" to compromise with a "Vasy! raconte tout de même! Je t'écoute avec une seule narine". (OP 846) The fables recounted by the Vase, illustrating the reign of chaos, randomness, and chance, prove, however, by their very seduction, too unpalatable for the Poet. The double has overstepped his limits, he has abused his freedom of thought and expression, he has gone much too far. And moreover, having concluded his fable about Chaos, the Vase extinguishes itself, leaving the Poet with no recourse except a futile and impotent gesture of rage:

C'est stupide! ça n'a pas de sens! je n'ai jamais entendu quelque chose d'aussi parfaitement insipide! Et d'ailleurs ça y est! ça s'est éteint dans ton ventre. Tu es froid, tu sens mauvais, pouah! c'est comme un renvoi d'ivrogne! Va-t-en au diable! (OP 847)

The Vase d'encens, the Poet's created double, has escaped the Poet's control, and really become Other. The "va-t-en au diable", thus, can be read, not merely as a common locution expressing exasperation, but as a literal send off to Satan, whose ideas the Vase was beginning to preach. And though the Poet catches himself before being seduced by the fables of the Vase, it has nevertheless succeeded in transferring some of its qualities to the Poet. And thus, the Poet, all heated up, and thoroughly incensed, hurls the Vase out the window.

The preceding analyses demonstrate how, in my view, the complex modes of theatricalization of the self, through various kinds of doubles, in diverse conversations and monologues, provide a measure of Claudel's position vis-à-vis the Orient. The surer the author is of his arguments and beliefs, the more these texts appear to be monologues. In situations where the author feels ambiguity and ambivalence, the preferred form is either a polyphonic dialogue involving multiple, albeit unidimensional characters, or a dialogue between a figurehead double and the Poet, providing the latter with a mechanism of distantiation, of disclaiming the double's opinions and ideas. 
The Poet and his Doubles: Claudel's Orientalism

\section{Notes}

1 Note 1 re. La Légende de Prâkriti, in the Pléiade edition of Claudel's CEurres en prose (henceforward referred to as $\mathrm{OP}$ ), edited by Jacques Petit and Charles Galpérine. Paris: Gallimard, 1965. p 1526. All quotations in this essay are from the same edition.

2 Rimbaud. Oeuvres Complètes. Paris: Editions Gallimard, 1972, in the letters to Georges Izambard and Paul Demeny, pp 249 and 250. 